\title{
Synaptic Compensatory Mechanism and its Impairment in Autoimmune Myasthenic Diseases
}

\author{
Masaharu Takamori* \\ Neurological Center, Kanazawa-Nishi Hospital, Kanazawa, Ishikawa, 920-0025, Japan
}

\section{Article Info}

\section{Article Notes}

Received: May 26, 2019

Accepted: June 26, 2019

\section{*Correspondence:}

Dr. Masaharu Takamori, Neurological Center, KanazawaNishi Hospital, Kanazawa, Ishikawa, 920-0025, Japan; Telephone No: +81-76-233-1811; Fax No: +81-76-221-8603 Email: m-takamori@vanilla.ocn.ne.jp.

(c) 2019 Takamori M. This article is distributed under the terms of the Creative Commons Attribution 4.0 International License.

\section{Keywords:}

Neuromuscular junction

Synaptic homeostasis

Myasthenia gravis

Lambert-Eaton myasthenic syndrome

Muscarinic acetylcholine receptor (mAChR)

Transient receptor potential canonical (TRPC)

\section{ABSTRACT}

The neuromuscular junction (NMJ) is organized by a complex architecture and various signals orchestrated by sophisticated interactions. They include the presynaptic $\mathrm{Ca}^{2+}$ homeostasis for acetylcholine ( $\mathrm{ACh}$ ) release in the active zone organization, the post-synaptic $A C h$ receptor $(A C h R)$ clustering at endplate membranes, the trans-synaptic communication from muscle to nerve, and the synaptic stabilization. The present data and discussions are concerned in an adaptive change of $\mathrm{ACh}$ release from the nerve terminal and its immunological impairment in the post-synaptic disease (myasthenia gravis, MG) and the presynaptic disease (Lambert-Eaton myasthenic syndrome, LEMS). Discussions mainly focus the antibody-induced failure of the synaptic compensatory mechanisms that are brought about by the presynaptic autoreceptors (the M1type muscarinic AChR [mAChR] cooperated with adenosine receptors), and the non-voltage-gated $\mathrm{Ca}^{2+}$-dominant influx channel (transient receptor potential canonical [TRPCs], particularly its phenotype TRPC3). Besides the synaptic transmission fatigue, the TRPC3 antibodies are discussed in terms of their implication in the muscle contraction fatigue that often occurs in the thymomaassociated MG and reflects a defect in the physiological association of TRPC3 with the ryanodine receptor- 1 in the excitation-contraction coupling in which the sarcoplasmic $\mathrm{Ca}^{2+}$ release takes place. In addition to the modulating role in the NMJ functions, the mAChRs participate in the innate and adaptive inmmunity by MG thymus and in the lung cancer (often associated with LEMS) growth.

Post-synaptic organization and its contribution to transsynaptic communication

In the neuromuscular junction, the presynaptic calcium homeostasis for acetylcholine (ACh) release and the postsynaptic nicotinic ACh receptor (nAChR) clusters anchored to the membrane by rapsyn (immobilized by heat-shock proteins) are modulated by the molecular mechanisms underlying synaptic plasticity. ${ }^{1-4}$ The former depends on functional organizations including the active zone architecture (piccolo, bassoon, RIM, RIM-BP, ELKS, Munc 13, $\alpha$-liprin, Munc 18, complexin, Neurexins, etc.), calcium channels, SNARE complex, synaptotagmins, synaptic vesicles and presynaptic autoreceptors ${ }^{5-9}$; the latter depends on agrin, Wnts (wingless integration site family of glycoproteins), Lrp4 (lowdensity lipoprotein receptor-related protein 4), MuSK (musclespecific tyrosine kinase) and Dok 7 (downstream kinase 7). ${ }^{10-18}$ The postsynaptic structure to be precisely opposed to the nerve terminal is stabilized by the extracellular matrix (including synaptic collagens such as Q, IV and XIII, perlecan, biglycan, laminins and $\alpha$-dytroglycan) and dystrophin-associated glycoprotein complex (including $\beta$-dystroglycan [linking to rapsyn and utophin], cortactin 
(acting as a synaptic kinase substrate and a regulator of actin polymerization), caveolin 3 , coronin 6 , $\alpha$-dystrobrevin (conducted by neuregulin 1-Erb B receptor interaction), and Sorbs $1 / 2$ (conducted by Dok7-Crk-L). ${ }^{19-34}$

In the trans-synaptic communication (Figure 1), the signals are mediated via (1) the Wnt canonical signaling by way of Wnt-MuSK Ig 4 (cysteine-rich domain)/Dishevelled (scaffold protein)/ inhibition of glycogen synthase kinase $3 / \beta$-catenin/Slit 2 in the muscle $35-37 ;(2)$ muscle-derived Lrp-4 (eight low-density lipoprotein a [LDLa] repeats), ${ }^{38}$ interacting with an Lrp 4-binding protein in motor neuron $^{38,39}$; (3) muscle laminin $\beta 2$ tethering the P/Q-type and N-type voltage-gated calcium channels (VGCCs) to the presynaptic active zone via $\alpha 3$ integrin $^{40,41}$; (4) musclederived laminins $\alpha 4, \alpha 5$ and $\beta 2$ in the laminin-network including muscle-agrin. ${ }^{42,43}$ Neuregulin- $1{ }^{44}$ endostatin, ${ }^{45}$ and bone morphogenic protein pathway members ${ }^{46}$ have been suggested as candidate retrograde signaling molecules. ${ }^{47}$

Modes of compensatory vesicle endocytosis in the nerve terminal

The fast-mode of endocytosis (clathrinindependent synaptic vesicle recycling) operates by

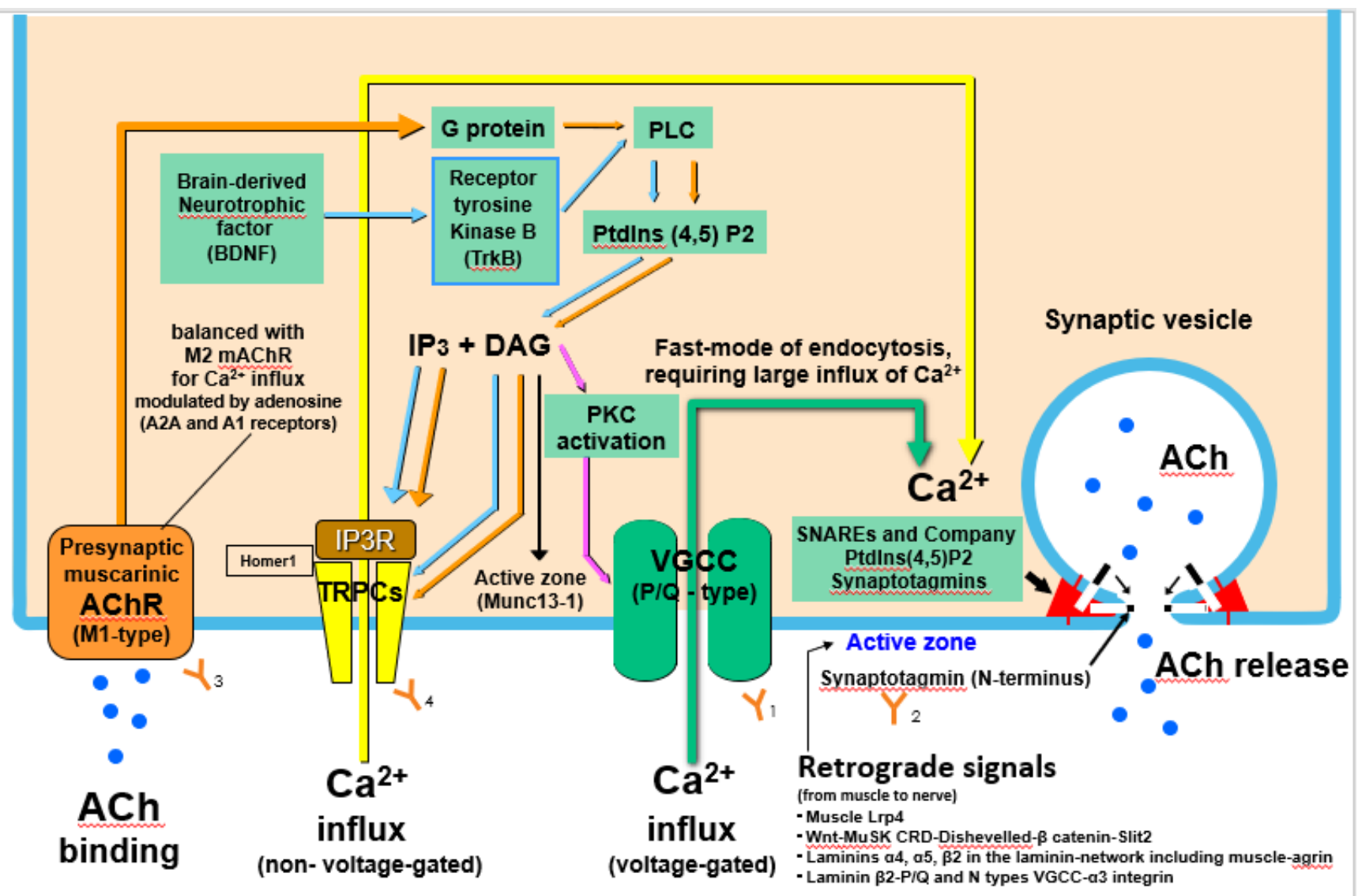

Figure 1: Schematic presentation of acetylcholine (ACh) release which is upregulated to compensate presynaptic dysfunctions by the homeostatic mechanisms operating in the active zone of the nerve terminal.

The fast-mode of endocytosis (clathrin-independent synaptic vesicle recycling) requires a large influx of external $\mathrm{Ca}^{2+}$ to compensate postsynaptic dysfunction. This homeostatic $\mathrm{Ca}^{2+}$ is promoted by phospholipase C (PLC) activation via the activation of G-protein-coupled receptor, such as the presynaptic M1-type muscarinic acetylcholine receptor (mAChR), and also via the interaction of brain-derived neurotrophic factor (BDNF) with receptor tyrosine kinase (TrkB). These biological mechanisms share a common pathway mediated by $\mathrm{PLC} /$ phosphatidylinositol-4,5-bisphosphate (Ptdins $(4,5) \mathrm{P} 2$ )/diacylglycerol (DAG)/protein kinase C (PKC); these in turn potentiate Ca ${ }^{2+}$ influx voltage-dependently via DAG/PKC-activated P/Q-type voltage-gated $\mathrm{Ca}^{2+}$ channel [VGCC] and voltage-independently via DAG-activated transient receptor potential canonical (TRPCs). The interaction of inositol-1,4,5-triphosphate (IP3) with IP3 receptor (IP3R) allows the TRPC-mediated $\mathrm{Ca}^{2+}$ influx to be free from the inhibitory control by scaffolding protein, Homer1. DAG also regulates the vesicle priming protein (Munc13-1) to recruit ACh-containing vesicles for immediately releasable pool in the active zone of the nerve terminal. In the physiologic condition, the mechanisms to control $\mathrm{Ca}^{2+}$ influx is based on the balance between the promotive effect by M1-type mAChR and the inhibitory effect by M2-type mAChR (modulated by adenosine and TrkB). The presynaptic architecture including SANREs (synaptobrevin, syntaxin and SNAP-25) and Company are detailed in references 5-9. Retrograde signals (from muscle to nerve) organize the active zone architecture contributing to synaptic vesicle recycling for ACh release. Y1: P/Q-type VGCC antibodies; Y2: antibodies to the extracellularly exposed segment of synaptotagmin 1 (N-terminus) during exocytosis; Y3: antibodies to M1-type mAChR; Y4: antibodies to TRPC3. 
promoting recruitment of dynamin 1/synaptophysin/ synaptobrevin $^{48,49}$ or by calcium/calmodulin/calcinulin/ dynamin signaling (endocytosis overshoot) ${ }^{50}$; these mechanisms require a large influx of external calcium. ${ }^{51-}$ ${ }^{54}$ (Figure 1). This homeostatic calcium influx is promoted by the activation of G protein-coupled receptors (GPCRs), such as the presynaptic M1-type muscarinic acetylcholine receptor $(\mathrm{mAChR})$ and adenosine receptor $\left(\mathrm{A} 2 \mathrm{~A}_{\mathrm{A}}\right)^{55-57}$ and the interaction of brain-derived neurotrophic factor (BDNF) with receptor tyrosine kinase (TrkB) in the nerve terminal ${ }^{58,59}$ (Figure 1). The positive effect of calcium influx by the M1-type mAChR-mediated signal is kept in balance with inhibitory presynaptic M2-type mAChR/protein kinase A signaling; the balance is modulated by adenosine (receptors: A2A for activation; A1 for inhibition) and $\operatorname{TrkB}^{55-57,60}$ (Figure 1).

The mechanisms for the positive effect of GPCR (M1-type mAChR) and BDNF share a common biological pathway mediated by phospholipase C(PLC)/ phosphatidylinositol-4,5-bisphosphate (PIP2)/diacylglycerol (DAG)/protein kinase C (PKC); these biological mechanisms stimulate the $\mathrm{P} / \mathrm{Q}$-type voltage-gated calcium channel (VGCC) ${ }^{55,58}$ (Figure 1). The PLC-generated DAG activates the non-voltage-gated calcium-dominant channel (transient receptor potential canonical [TRPC] 3, 6 and 7) ${ }^{61,62}$ and also regulates the vesicle priming protein (Munc13-1) to recruit ACh containing vesicles for the immediately releasable pool. ${ }^{63}$ (Figure 1). The PLC-generated inositol triphosphate (IP3) interacts with the IP3 receptor; this allows the TRPCmediated calcium influx to be free from inhibitory control by scaffolding protein, Homer $1^{64}$ (Figure 1). Among the seven members in TRPC family, TRPC3, TRPC6 and TRPC7 are the close homologues; it is structurally confirmed that the TRPC3 is abundantly expressed in the nervous system and has a unique feature with the remarkable long S1-S4 domain stretching into the extracellular side and supporting the formation of the extracellular domain; 65 thereby, the TRPC3 could be accessible to antibodies in the manner similar to the M1-type mAChR containing the extracellularly exposed domain. ${ }^{66}$ The M1-type mAChR is physiologically associated with the non-voltage-gated channel (TRPC)-mediated calcium influx ${ }^{67}$ (as shown by brown and blue lines with arrow-head in Figure 1). This association may thus be cooperative to act on the mechanism and function compensating synaptic disorders. As mentioned above, however, we should take notice that the large $\mathrm{Ca}^{2+}$ influx for the compensatory presynaptic mechanisms via M1-type mAChR, TRPCs/IP3R and adenosine A2A receptor are controlled (in order to prevent injurious $\mathrm{Ca}^{2+}$-excess in the nerve terminal) by the balance with the inhibitory mechanisms based on M2-type mAChR, Homer 1, adenosine A1 receptor and TrkB.
Immunology in myasthenia gravis and LambertEaton myasthenic syndrome focusing presynaptic autoreceptors and channels for synaptic compensatory mechanisms

In view of the above-mentioned synaptic physiology, serum samples from myasthenia gravis (MG) and LambertEaton myasthenic syndrome (LEMS) were assayed by immunoblotting using the human M1-type mAChR fusion protein, ${ }^{68}$ and by ELISA using the peptide synthesized based on the sequences of the human TRPC3 (extracellularly exposed segment: Phe611-His640). ${ }^{69}$ Of 25 MG patients with postsynaptic nAChR antibodies, seven (28\%) were positive for presynaptic M1-type mAChR antibodies, ${ }^{68}$ and $9(36 \%)$ were positive for TRPC3 antibodies ${ }^{69}$ (Table 1). The clinical severity of these patients (graded by Myasthenia Gravis Foundation of America, MGFA, Clinical Classification ${ }^{70}$ ) tends toward higher, more severe grades, ${ }^{68,69}$ suggesting that their synaptic functions may not be adequate to upregulate ACh quantal release to compensate postsynaptic defect.

Reportedly, the electrophysiological study in MG with AChR antibodies showed that the compensatory ACh release upregulation cannot be sustained at the high frequency of nerve stimulation, ${ }^{71}$ possibly because the reduction in homeostatic small reserve pool of vesicles that depends on presynaptic adenosine $\mathrm{A} 2 \mathrm{~A}$ receptor operating $\mathrm{Ca}^{2+}$ influx via L-type VGCC. ${ }^{72-74}$ In a long-tetanic load in muscle, the complex compensatory mechanisms including the presynaptic autoreceptor and channel in this signaling pathway may underlie to compensate postsynaptic dysfunction.

As an additional consideration to the physiological role of TRPC3, it is worthy to note that the TRPC3 takes part in muscle contraction in addition to above-mentioned synaptic transmission. Many of the severe-graded MG patients studied herein have thymoma and are positive for antibodies to the ryanodine receptor 1 (RyR1) (Table 1). RyR1 activates the sarcoplasmic $\mathrm{Ca}^{2+}$ release in the excitation-contraction coupling via membranedepolarization $^{75}$; this cooperates with TRPC3 which is activated by PLC-PIP2-DAG signaling pathway ${ }^{76,77}$ and conducts the activating signal to RyR1 via triadic bridging proteins, including TRPC1 and possibly coregulatory proteins (junctophyins 1 and 2, homer, mitsugumin 29, calreticulin and calmodulin). ${ }^{78,79}$ In our experiment (Table 1), three synthetic RyR1 peptides were used as antigens to determine antibodies: (1) the residues 1191-1216 (a region toward the $\mathrm{N}$-terminus that faces the loop between domains II and III of dihydropyridine receptor [voltage sensor]), ${ }^{80}$ (2) the residues 4997-5017 (C-terminal transmembrane segment, which is expressed in thymoma epithelial cells and is suspected of inducing breakdown in tolerance to RyR1), ${ }^{81}$ and (3) the residues 5019-5038 (C-terminal tail which protrudes into cytoplasm outside the 
Table 1: Clinical and immunological profiles in 25 patients with myasthenia gravis.

\begin{tabular}{|c|c|c|c|c|c|c|c|c|c|}
\hline \multirow[t]{2}{*}{$\begin{array}{l}\text { No. of } \\
\text { Patients }\end{array}$} & \multirow[t]{2}{*}{$\begin{array}{l}\text { Gender } \\
\text { (M:male, } \\
\text { F:female)/ } \\
\text { age at onset } \\
\text { (years) }\end{array}$} & \multirow[t]{2}{*}{$\begin{array}{l}\text { MGFA } \\
\text { grades }\end{array}$} & \multirow[t]{2}{*}{ Thymoma } & \multirow[t]{2}{*}{$\begin{array}{l}\text { AChR } \\
\text { (nM) } \\
\text { (contro:I }<0.1 \text { ) }\end{array}$} & \multirow[t]{2}{*}{$\begin{array}{l}\text { M1 mAChR } \\
\text { (immunoblots) }\end{array}$} & \multirow[t]{2}{*}{$\begin{array}{l}\text { Antibodies to } \\
\text { TRPC3 } \\
\text { (ELISA) } \\
\text { (control: <0.17 } \\
\text { at OD450) }\end{array}$} & \multicolumn{3}{|c|}{$\begin{array}{l}\text { RyR1 } \\
\text { (ELISA) } \\
\text { (control: <0.10 } \\
\text { at OD450) }\end{array}$} \\
\hline & & & & & & & $\mathbf{N}$ & C-tr & C \\
\hline 1 & $F / 58$ & $\mathrm{IVb}$ & Yes & 18 & - & 0.18 & - & + & + \\
\hline 2 & M 35 & IVa & Yes & 31 & + & 0.22 & + & + & + \\
\hline 3 & $F / 36$ & Illb & Yes & 31.3 & + & 0.22 & - & + & + \\
\hline 4 & $\mathrm{~F} / 22$ & IIIlb & Yes & 47 & - & 0.26 & - & + & + \\
\hline 5 & $\mathrm{~F} / 20$ & IIIlb & Yes & 0.6 & - & 0.16 & - & + & + \\
\hline 6 & $\mathrm{~F} / 37$ & Illlb & Yes & 1.6 & + & 0.72 & - & + & + \\
\hline 7 & $M / 56$ & Illb & Yes & 9.8 & + & 0.10 & - & + & + \\
\hline 8 & $F / 36$ & Illlb & Yes & 3.2 & + & 0.04 & + & + & + \\
\hline 9 & $F / 22$ & Illb & Yes & 120 & - & 8.12 & - & + & + \\
\hline 10 & $M / 44$ & IIIlb & Yes & 41 & - & 0.16 & + & + & + \\
\hline 11 & $\mathrm{~F} / 53$ & Illlb & Yes & 41 & - & 0.02 & - & + & + \\
\hline 12 & $M / 43$ & IIIb & Yes & 220 & - & 0.729 & - & + & + \\
\hline 13 & $\mathrm{~F} / 25$ & IIIlb & No & 5.8 & + & 0.20 & - & - & - \\
\hline 14 & $M / 40$ & Illa & Yes & 5.6 & - & 0.05 & - & + & + \\
\hline 15 & $F / 64$ & IIIa & Yes & 33 & - & 0.08 & - & + & + \\
\hline 16 & $\mathrm{~F} / 42$ & IIIa & Yes & 20 & - & 0 & - & + & - \\
\hline 17 & $F / 19$ & IIIa & (Hyperplasia) & 69 & - & 0.62 & - & - & + \\
\hline 18 & $\mathrm{~F} / 70$ & IIIa & No & 43 & + & 0.04 & - & - & - \\
\hline 19 & $F / 65$ & Illa & No & 47 & - & 0.07 & - & - & - \\
\hline 20 & $F / 18$ & Illa & No & 19 & - & 0.06 & + & - & - \\
\hline 21 & $M / 65$ & IIlla & No & 120 & - & 0.02 & - & - & - \\
\hline 22 & $\mathrm{~F} / 45$ & IIIIa & (Hyperplasia) & 200 & - & 0 & - & - & - \\
\hline 23 & F / 29 & llb & No & 77 & - & 0.02 & - & - & - \\
\hline 24 & $M / 23$ & llb & Yes & 67 & - & 0 & - & - & - \\
\hline 25 & $\mathrm{~F} / 57$ & Ila & No & 73 & - & 0.04 & + & - & - \\
\hline
\end{tabular}

Referred to references 68,69 and 89. MGFA, Myasthenia Gravis Foundation of America; AChR, acetylcholine receptor; M1 mAChR, M1-type muscarinic acetylcholine receptor; TRPC3, Transient receptor potential classical isoform-3; RyR1, ryanodine receptor-1; $\mathrm{N}$ : N-terminus (residues 1191-1216); C-tr:C-terminal transmembrane (residues 4997-5017); C: C-terminal tail (residues 5019-5038). RyR1 antibodies determined by ELISA at OD450: expressed by + (positive, above 0.10 ) and - (negative, below 0.10 ). None of 25 patients showed antibodies to IRPC3 (data not shown).

Table 2: Clinical, electrophysiological and immunological profiles in 25 patients with Lambert-Eaton myasthenic síndrome.

\begin{tabular}{|c|c|c|c|c|c|c|c|}
\hline $\begin{array}{l}\text { No. of } \\
\text { patient }\end{array}$ & $\begin{array}{l}\text { Gender } \\
\text { (M:male, s } \\
\text { F:female)/ } \\
\text { age at onset } \\
\text { (years) }\end{array}$ & $\begin{array}{l}\text { Amplitude of } \\
\text { single CMAP } \\
(\mathrm{mV}) \\
\end{array}$ & $\begin{array}{c}\text { Potentiation } \\
\text { at } 50 \mathrm{~Hz} \text { RNS } \\
(\%)\end{array}$ & SCLC & $\begin{array}{l}\quad \text { A } \\
\text { P/Q-type } \\
\text { VGCC } \\
\text { (pM) } \\
\text { (control, } \\
<20) \\
\end{array}$ & $\begin{array}{l}\text { Intibodies } \\
\text { Synpt I } \\
\text { (control, } \\
<0.19 \text { ) } \\
\text { (ElLA } \\
\text { at OD450) }\end{array}$ & $\begin{array}{l}\text { s to } \\
\text { M1 mAChR } \\
\text { (immunoblot) }\end{array}$ \\
\hline 1 & $M / 64$ & 1.8 & 500 & Yes & 1275 & 0 & + \\
\hline 2 & $M / 55$ & 1.0 & 133 & Yes & 1481 & 1.90 & + \\
\hline 3 & $M / 62$ & 1.0 & 600 & Yes & 216 & 0 & + \\
\hline 4 & $M / 58$ & 2.1 & 122 & Yes & 124 & 0.03 & - \\
\hline 5 & $M / 74$ & 3.0 & 242 & Yes & 138 & 1.40 & + \\
\hline 6 & $M / 68$ & 0.4 & 804 & Yes & 6303 & 0.02 & + \\
\hline 7 & $M / 41$ & 1.5 & 200 & Yes & 236 & 0.01 & + \\
\hline 8 & $M / 57$ & 0.3 & 979 & Yes & 256 & 0 & - \\
\hline 9 & $M / 47$ & 2.7 & 200 & Yes & 342 & 0.02 & - \\
\hline 10 & $M / 67$ & 0.5 & 700 & Yes & 1216 & 0 & + \\
\hline 11 & $M / 68$ & 2.5 & 480 & Yes & 1814 & 0 & - \\
\hline 12 & $M / 68$ & 1.4 & 484 & Yes & 381 & 0.07 & + \\
\hline 13 & $M / 68$ & 3.1 & 200 & Yes & 43 & 0.05 & + \\
\hline 14 & $M / 68$ & 1.7 & 290 & Yes & 148 & 2.16 & - \\
\hline
\end{tabular}

Referred to references 85-89. CMAP, compound muscle action potential; RNS, repetitive nerve stimulation;SCLC, small-cell lung carcinima; VGCC, voltage-

\begin{tabular}{|c|c|c|c|c|c|c|c|}
\hline $\begin{array}{l}\text { No. of } \\
\text { patient }\end{array}$ & $\begin{array}{l}\text { Gender } \\
\text { (M:male, } \\
\text { F:female)/ } \\
\text { age at onset } \\
\text { (years) }\end{array}$ & $\begin{array}{l}\text { Amplitude of } \\
\text { single CMAP } \\
(\mathrm{mV})\end{array}$ & $\begin{array}{c}\text { Potentiation } \\
\text { at } 50 \mathrm{~Hz} \text { RNS } \\
(\%)\end{array}$ & SCLC & $\begin{array}{l}\quad \text { Ar } \\
\text { P/Q-type } \\
\text { VGCC } \\
\text { (pM) } \\
\text { (control, } \\
<20 \text { ) } \\
\end{array}$ & $\begin{array}{l}\text { ntibodies } \\
\text { Synpt } \\
\text { (control, } \\
\text { <0.19) } \\
\text { (ElsA } \\
\text { at OD450) } \\
\end{array}$ & $\begin{array}{l}\text { sto } \\
\text { (mi mAChR } \\
\text { (mmoblot) }\end{array}$ \\
\hline 15 & $M / 62$ & 1.3 & 670 & No & 136 & 0.01 & + \\
\hline 16 & $M / 67$ & 1.0 & 740 & No & 8235 & 0.07 & - \\
\hline 17 & $M / 63$ & 1.5 & 233 & No & 2068 & 0 & + \\
\hline 18 & $M / 69$ & 0.1 & 220 & No & 49 & 5.42 & + \\
\hline 19 & $M / 74$ & 0.5 & 570 & No & 3805 & 0 & + \\
\hline 20 & $M / 58$ & 0.4 & 340 & No & 343 & 0 & + \\
\hline 21 & $\mathrm{~F} / 55$ & 0.8 & 370 & No & $<1.0$ & 0 & + \\
\hline 22 & $M / 63$ & 1.8 & 267 & No & $<1.0$ & 0.01 & + \\
\hline 23 & $F / 63$ & 0.8 & 541 & No & $<1.0$ & 2.20 & + \\
\hline 24 & $M / 68$ & 0.7 & 200 & No & $<1.0$ & 0 & + \\
\hline $25^{*}$ & M/79 & 2.6 & 257 & Yes & $<1.0$ & 0 & + \\
\hline
\end{tabular}

this presynaptic disorder, the pathogenicity of which has mainly referred to the antibodies directing to presynaptic components, P/Q-type VGCC and synaptotagmin $1 .{ }^{85-88}$ In 25 LEMS patients whose diagnosis was electrophysiologically confirmed (low amplitude of muscle action potential evoked with single nerve stimulation and its marked potentiation after tetanic nerve stimulation), 19 patients (76\%), 4 of whom were negative for antibodies to both P/Q-type VGCC and synaptotagmin 1, were positive for presynaptic M1type mAChR antibodies ${ }^{68,85,89}$ (Table 2). Passive transfer carcinoma (SCLC) expressing antigens immunologic cross-reactive with the nerve terminal proteins, we showed that M1-type mAChR antibodies are implicated in 
of serum IgG from a patient solely positive for presynaptic M1-type mAChR antibodies to mouse produced the electrophysiological features of LEMS (reduced ACh quantal contents confirmed by the microelectrode study). ${ }^{89}$ The compensatory mechanism that activates presynaptic M1-type mAChR and modulates the fast-mode of synaptic vesicle recycling may be restricted by coincident M1-type mAChR antibodies in LEMS. ${ }^{85,89}$ Pharmacologically, ACh quantal release is reduced by specific M1-type mAChR blockade in mice at standard ion concentrations without added drugs ${ }^{90}$; this helps us understand the presynaptic M1-type mAChR-dependent compensatory mechanism and its impairment in immunological synaptic disorders. None of 25 patients with LEMS showed antibodies to TRPC3 (studied as disease control for myasthenia gravis). ${ }^{69}$

Thymus in myasthenia gravis and cancer in LambertEaton myasthenic syndrome

The MG thymus play a pivotal role in the pathogenesis of the disease. The hyperplastic MG thymus contains the components necessary for an anti-nAChR immune response including activated autoreactive $B$ and $T$ cells, the antigen-presenting cells, the autoantigen and the activated complement receptors in the epithelial cells. ${ }^{91,92}$ The thymoma-associated MG brings about the abnormal T cell selection caused by the defective expression of tolerogenic autoimmune regulator (AIRE)-positive thymic medulla, the epithelial cells defective in the expression of HLA class II molecules, the lack or reduction of immune-tolerated AChR-positive myoid cells and the failure to generate $\mathrm{CD} 4^{+}$, $\mathrm{CD}^{2} 5^{+}$and Fox P3-positive regulatory T cells. ${ }^{93}$ The mTOR (mammalian target of rapamycin)/Akt (serine/threonine kinase) pathway participates to the cell proliferation associated with thymoma growth. ${ }^{94,95}$ In the innate and adaptive immunity in MG thymus, the crosstalk between the complement (C5a and $\mathrm{C} 3 \mathrm{a}$ ) and the Toll-like receptors in thymic epithelial cells causes (1) promoting abnormal B cell activation, leading to ectopic germinal center development; (2) Th1/Th17-related pro-inflammatory cytokine production based on T cells disproportion (Th effector $>$ Th regulator); (3) antigen-presentation by dendritic cells recruited by chemokine (CCL17 and CCL22). ${ }^{95,96}$ The inflammatory cytokine elevation are brought about by the activation of mitogen-activated protein kinases (MAPKs), transcriptional nuclear factor- $\kappa \mathrm{B}(\mathrm{NF}-\kappa \mathrm{B})$ and activated protein-1 (AP-1). ${ }^{97}$ The mAChRs (M1 and M5) expressed in thymocytes and lymphocytes contribute to the regulation of pro-inflammatory cytokine production related to adaptive immunity. ${ }^{98,99}$ In view of the MG immune pathogenicity, the target-specific immunotherapies are developing; the specific therapies are adapted or in expectation of trial to the MG patients refractory to thymectomy and/or usual immunosuppressants by use of (1) IgG- $\kappa$ chain targeting CD20 B-cell antibody, ${ }^{100}$ (2) Complement C5 inhibitors, ${ }^{101,102}$
(3) antibody to cytotoxic T lymphocyte antigen, ${ }^{103}$ (4) IL-6 receptor blocker, ${ }^{104}(5)$ IL-10 modulated human dendritic cells to generate regulatory $\mathrm{T}$ cells (to be superior to effector T cells), ${ }^{105}$ (5) recombinant AChR fragment for antigen-specific removal of AChR antibodies, ${ }^{106}$ (6) human neonatal Fc receptor blocker, ${ }^{107}$ (7) selective inhibitor of immunoproteasome, ${ }^{108}$ and (8) inhibitor of inflammatory factors via TRL2/4-P13K-NFKB signaling. ${ }^{109}$

The SCLC, which tends to associate with LEMS, expresses mAChRs ${ }^{110}$ as well as VGCC ${ }^{111-113}$ and synaptotagmins, ${ }^{114}$ suggesting that the antibodies to neuronal antigens expressed in SCLC corss-react with those on nerve terminals leading to the neurological defects. ${ }^{115}$ Besides the functional role as the presynaptic autoreceptor which modulates the synaptic transmission, the mAChRs are expressed in lung cancer and their activation (via the cholinergic autocrine loop expressed in cancer and stimulated by ACh secreted by cancer) provides an effect for cancer growth via the activation in mitogen-activated protein kinase and serine/threonine kinase Akt (involved in the phosphatidylinositol-3 kinase signaling pathway). ${ }^{110,116}$

\section{References}

1. Shi L, Fu AKY, Ip NY. Molecular mechanisms underlying maturation and maintenance of the vertebrate neuromuscular junction. Trends Neurosci. 2012; 35 (7): 441-453.

2. Wu H, Xiong WC, Mei L. To build a synapse: signaling pathway in neuromuscular junction assembly. Development 2010; 137 (7): 10171033.

3. Takamori M. Synaptic homeostasis and its immunological disturbance in neuromuscular junction disorders. Int J Mol Sci. 2017; 18 (4): 896908.

4. Burden SJ, Huijber, MG, Remedio L. Fundamental molecules and mechanisms for forming and maintaining neuromuscular synapses. Int J Mol Sci. 2018; 19 (2): 490-509.

5. Südhof TC. The presynaptic active zone. Neuron 2012; 75 (1): 11-25.

6. Tian X, Wu C. Active zone stability: Insights from fly neuromuscular junction. Neuronal Regen Res. 2015; 10 (5): 677-680.

7. Jung H, Szule JA, Marshall RM, et al. Variable priming of a docked synaptic vesicle. Proc Nat Acad Sci USA. 2016:;113 (8): E1098-1107.

8. Körber C, Kuner T. Molecular machines regulating the release probability of synaptic vesicles at the active zone. Front Synaptic Neurosci. 2016; 8: 5.

9. Harris KP, Lettleton JT. Transmission, development and plasticity of synapses. Genetics 2015; 201(2): 345-375.

10. Burden SJ, Yumoto N, Zhang W. The role of MuSK in synapse formation and neuromuscular disease. Cold Spring Harb Perspect Biol. 2013; 5(5): a009167.

11. Strochlic L, Falk J, Goillot E, et al. Wnt4 participates in the formation of vertebrate neuromuscular junction. PLoS One 2012; 7(1): e29976.

12. Koles K, Budnik V. Wnt signaling in neuromuscular junction development. Cold Spring Harb Perspect Biol. 2012; 4(6): a008045.

13. Zong Y, Jin R. Structural mechanisms of the agrin-Lrp4-MuSK signaling pathway in neuromuscular junction differentiation. Cell Mol Life Sci. 2013; 70(17): 3077-3088. 
14. Weatherbee SD, Anderson,KV, Niswander LA. LDL-receptor-related protein 4 is crucial for formation of the neuromuscular junction. Development 2006; 133(24): 4993-5000.

15. Zang B, Luo S, Wang Q, et al. Lrp4 serves as a coreceptor for agrin. Neuron 2008; 60(2): 285-297.

16. Kim N, Stiegler A, Cameron TO, et al. Lrp4 is a receptor for agrin and forms a complex with MuSK. Cell 2008; 135(2): 334-342.

17. Hallock PT, Xu CF, Park TJ, Neubert TA, Curran T, Burden SJ. Dok 7 regulates neuromuscular synapse formation by recruiting Crk and Crk-L. Genes Dev. 2010; 24(21): 2451-2461.

18. Bergamin E, Hallock PT, Burder SJ, et al. The cytoplasmic adaptor Protein Dok7 activates the receptor tyrosine kinase MuSK via dimerization. Mol Cell. 2010; 39(1): 100-109.

19. Consantin B. Dystrophin complex functions as a scaffold for signaling proteins. Biochem Biophys Acta. 2014; 1838(2): 635-642.

20. Hochenester E, Yurchenco PD. Laminins in basement membrane assenmbly. Cell Adh Migr. 2013; 7(1): 56-63.

21. Yurchenco PD. Basement membrane: cell scaffolding and signaling platforms. Cold Spring Harb Perspect Biol. 2011; 3(2): a00491.

22. Singhal N, Martin PT. Role of extracellular matrix proteins and their receptors in the development of the vertebrate neuromuscular junction. Dev Neurobiol. 2011; 71(11): 982-1005

23. Pilgram GSK, Potikanons S, Baines RA, et al. The roles of the dystrophin-associated glycoprotein complex at the synapse. Mol Neurobiol. 2010; 41(1): 1-21.

24. Karmouch J, Dobbertin A, Sigoillot S, et al. Developmenta Consequences of the ColQ/MuSK interactions. Chem Biol Interact. 2013; 203(1): 287-291.

25. Amenta AR, Creely HE, Mercado ML, et al. Biglycan is an extracellular MuSK binding protein important for synapse stability. J Neurosci. 2012; 32(7): 2324-2334.

26. Nastase MV, Young MF, Schaefer L. Biglycan: a multivalent proteoglycan providing structure and signals. J Histochem Cytochem. 2012; 60((12): 963-975.

27. Takamori M. Pathogenic participation of MuSK-Biglycan linkage contributive to synaptic stability and signaling in myasthenia gravis. J Autoimmun Disord. 2017; 3(3): 41-48.

28. Hallock PT, Chin S, Blaid S, et al. Sorbs 1 and 2 interact with Crk-L and are required for acetylcholine receptor cluster formation. Mol Cell Biol. 2015; 36(2): 262-270.

29. Madhavan R, Gong ZL, Ma JJ, et al. The function of cortactin in the clustering of acetylcholine receptors at the vertebrate neuromuscular junction. PLoS One 2009; 4(12): e8478.

30. Hezel M, de Groat WC, Calbiati, F. Caveolin-3 promotes nicotinic acetylcholine receptor clustering and regulates neuromuscular junction activity. Mol Biol Cell. 2010; 21(2): 302-310.

31. Chen Y, Ip FCF, Shi L, et al. Coronin 6 regulates acetylcholine receptor clustering through modulating receptor anchorage to actin cytoskeleton. J Neurosci. 2014; 34(7): 2413-2421.

32. Simeone L, Straubinger $\mathrm{H}$, Khan MA, et al. Identification of Erbin interacting MuSK and ErbB2 and its impact on acetylcholine receptor aggregation at the neuromuscular junction. J Neurosci. 2012; 30(19): 6620-6634.

33. Ngo ST, Cole RN, Sunn N, et al. Neuregulin-1 potentiates agrin-induced acetylcholine receptor clustering through muscle-specific kinase phosphorylation. J Cell Sci. 2012; 125(Pt 6): 1531-1543.

34. Schmidt N, Akaaboune M, Gajendran N, et al. Neuregulin/ErbB regulate neuromuscular junction development by phosphorylation of $\alpha$-dystrobrevin. J Cell Biol. 2011; 195(7): 1171-1184.
35. Wu H, Lu Y, Barik A, et al. $\beta$-catenin gain of function in muscles impairs neuromuscular junction. Development 2012; 139(13): 2392-2404.

36. Wu H, Barik A, Lu Y, et al. Slit2 as a $\beta$-catenin/Ctnnb1-dependent retrograde signal for presynaptic differentiation. Elife 2015; 4: e07266.

37. Salinas PC. Retrograde signaling at the synapse: a role for Wnt proteins. Biochem Soc Trans. 2005; 33(Pt6): 1295-1298.

38. Yumoto N, Kim N, Burden SJ. Lrp4 is a retrograde signal for presynaptic differentiation at neuromuscular synapses. Nature 2012; 489(7416): 438-442.

39. Wu H, Lu Y, Shen C, et al. Distinct roles of muscle and motoneuron Lrp4 in neuromuscular junction formation. Neuron 2012; 75(1): 94 107.

40. Carson SS, Valdez G, Sanes JR. Presynaptic calcium channels and $\alpha 3$ integrins are complexed with synaptic cleft laminins, cytoskeletal elements and active zone components. J Neurochem. 2010; 115(3): 654-666.

41. Nishimune $\mathrm{H}$. Molecular mechanism of active zone organization at vertebrate neuromuscular junctions. Mol Neurobiol. 2012; 45(1): 1-16.

42. Samuel MA, Valdez G, Tapia JC, et al. Agrin and synaptic laminin are required to maintain adult neuromuscular junctions. PLoS One 2012; 7(10): e46663.

43. Zang BG, Quigley AF, Bourke JL, et al. Combination of agrin and laminin increase acetylcholine receptor clustering and enhance functional neuromuscular junction formation in vitro. Dev Neurobiol. 2015; 76(5): 551-565.

44. Südhof TC. Neuregulin and neurexins link synaptic function to cognitive disease. Nature. 2008; 455(7215): 903-911.

45. Wang T, Hanswith AG, Tony A, et al. Endostatin is a trans-synaptic signal for homeostatic synaptic plasticity. Neuron 2014; 83(3): 616629.

46. Osses N, Henrequez JP. Bone morphogenic protein signaling in vertebrate motor neurons and neuromuscular communication. Front Cell Neurosci. 2014; 8: 453.

47. Plomp JJ. Trans-synaptic homeostasis at the myasthenic neuromuscular junction. Fron Biosci (Landmark Ed.). 2017; 22: 1033 1051.

48. Daly C, Ziff EB. Ca ${ }^{2+}$-dependent formation of a dynamin-synaptophysin complex. Potential role in synaptic vesicle endocytosis. J Biol Chem. 2002; 277(11): 9010-9015.

49. Deák F, Schoch S, Liu X, et al. Synaptobrevin is essential for fast synaptic-vesicle endocytosis. Nat Cell Biol. 2004; 6(11): 1102-1108.

50. Xue L, McNeil BD, Nu XS, et al. A membrane pool retrieved via endocytosis overshoot at nerve terminals: a study of its retrieval mechanism and role. J Neurosci. 2012; 32(10): 3398-3404.

51. Müller M, Davis GW. Trans-synaptic control of presynaptic $\mathrm{Ca}^{2+}$-influx achieves homeostatic potentiation of neurotransmitter release. Curr Biol. 2012; 22(12): 1102-1108.

52. $\mathrm{Wu} \mathrm{XS}, \mathrm{McNeil} \mathrm{BD}, \mathrm{Xu}$ J, et al. $\mathrm{Ca}^{2+}$ and calmodulin initiate all forms of endocytosis during depolarization at a nerve terminal. Nat Neurosci. 2009; 12(8): 1003-1010.

53. Wu LG, Hamid E, Shin W, et al. Exocytosis and endocytosis: modes, functions, and coupling mechanisms. Annu Rev Physiol. 2014; 76: 301-331.

54. Yamashita T. $\mathrm{Ca}^{2+}$-dependent regulation of synaptic vesicle endocytosis. Neurosci Res. 2012; 73(1): 1-7.

55. Santafé MM, Priego M, Obis T, et al. Adenosine receptors and muscarinic receptors cooperate in acetylcholine release modulation 
in the neuromuscular synapse. Eur J Neurosci. 2015; 42(2): 17751787.

56. Nadal L, Garcia N, Hurtado E, et al. Presynaptic muscarinic acetylcholine autoreceptors (M1, M2 and M4 subtypes), adenosine receptors ( $A 1$ and $A 2$ ) and tropomyosin-related kinase $B$ receptor (TrkB) modulate the developmental synapse elimination process at the neuromuscular junction. Mol Brain. 2016; 9(1): 67.

57. Tomòs J, Gracia N, Lanuza MA, et al. Adenosine receptors in developing and adult mouse neuromuscular junctions and functional links with other metabotropic receptor pathways. Front Pharmacol. 2018; 9: 397-406.

58. Amaral MD, Pozzo-Miller L. Intracellular $\mathrm{Ca}^{2+}$ stores and $\mathrm{Ca}^{2+}$ influx are both requires for BDNF to rapidly increase quantal vesicular transmitter release. Neural Plast. 2012; 2012: 203536.

59. Simó A, Just-Borrás L, Cilleros-Maňé V, et al. BDNF-TrkB signaling coupling to $\mathrm{nPKC} \varepsilon$ and $\mathrm{cPKC} \beta \mathrm{l}$ modulate the phosphorylation of the exocytotic protein Munc 18-1 during synaptic activity at the neuromuscular junction. Front Mol Neurosci. 2018; 11: 207-227.

60. Tomòs J, Santafé MM, Garcia N, et al. Presynaptic membrane receptors in acetylcholine release modulation in the neuromuscular synapse. J Neurosci Res. 2014;92(5): 543-554.

61. Santafé MM, Lanuza MA, Garcia N, et al. Coupling of presynaptic muscarinic autoreceptors to serine kinases in low and high release conditions on the rat motor nerve terminal. Neuroscience 2007; 148(2): 432-440.

62. Lemonnier L, Trebak M, Putney JW Jr. Complex regulation of the TRPC3,6 and 7 channel subfamily by diacylglycerol and phosphatidylinositol 4,5-bisphosphate. Cell Calcium. 2008; 43(5): 506-514.

63. Bauer CS, Woolley RJ, Teschemacher AG, et al. Potentiation of exocytosis by phospholipase C-coupled G-protein-coupled receptors requires the priming protein Munc 13-1. J Neurosci. 2007; 27(1): 212 219.

64. Yuan JP, Lee KP, Hong JH, et al. The closing and operating of TRPC channels by Homer 1 and STIM 1. Acta Physiol (Oxf). 2012; 204(2): 238-247.

65. Fan C, Choi W, Sun W, et al. Structure of the human lipid-gated cation channel TRPC3. Elife. 2018; 7: e36852.

66. Garcia N, Santafé MM, Salon I, et al. Expression of muscarinic acetylcholine receptors (M1-, M2-, M3- and M4-type) in the neuromuscular junction of the newborn and adult rat. Histol Histopathol. 2005; 20: 733-743.

67. Kim Y, Saffen D. Activation of M1 muscarinic acetylcholine receptors stimulates the formation of multiprotein complex centered on TRPC6 channels. J Biol Chem. 2005; 280(36): 32035-32047.

68. Takamori M, Motomura M, Fukudome T, et al. Autoantibodies against M1 muscarinic acetylcholine receptor in myasthenic disorders. Eur J Neurol. 2007; 14(11): 1230-1235.

69. Takamori M. Autoantibodies against TRPC3 and ryanodine receptor in myasthenia gravis. J Neuroimmunol. 2008; 200(1-2): 142-144.

70. Myasthenia gravis: recommendations for clinical research standards. Task force of the Medical Scientific Advisory Board of the Myasthenia Gravis Foundation of America. Neurology. 2000; 55(1): 16-23.

71. Plomp JJ, Morsch M, Phillips WD, et al. Electrophysiological analysis of neuromuscular synaptic function in myasthenia gravis patients and animal models. Exp Neurol. 2015; 270(270): 41-54

72. Wang X, Pinter MJ, Rich MM. Reversible recruitment of a homeostatic reserve pool of synaptic vesicles underlies rapid homeostatic plasticity of quantal content. J Neurosci. 2016; 36(3): 828-836.

73. Ma J, Kelly L, Ingram J, et al. New insights into short-term synaptic facilitation at the frog neuromuscular junction. J Neurophysiol. 2015; 113(1): 71-87.

74. Oliverira L, Timóteo MA, Correira-de-Sá P. Tetanic depression is overcome by tonic adenosine $\mathrm{A}(2 \mathrm{~A})$ receptor facilitation of L-type Ca $(2+)$ influx into rat motor nerve terminals. J Physiol. 2004; 560(Pt 1): 157-168.

75. Santulli G, Lewis OR, Marks AD. Physiology and pathophysiology of excitation-contraction coupling: the functional role of ryanodine receptor. J Muscle Cell Motil. 2017; 38(1): 37-45.

76. Gees M, Colsoul B, Nilius B. The role of transient receptor potential cation channels in $\mathrm{Ca}^{2+}$ signaling. Cold Spring Harb Perspect Biol. 2010; 2(10): a003962.

77. Birnbaumer L. The TRPC class of ion channels: a critical review of their roles in slow, sustained increases in intracellular $\mathrm{Ca}^{2+}$ concentrations. Annu Rev Pharmacol Toxicol. 2009; 49: 395-426.

78. Lee EH, Cherednichenko G, Pessah IN, et al. Functional coupling between TRPC3 and RyR1 regulates the expressions of key triadic proteins. J Biol Chem. 2006; 281(15): 10042-10048.

79. Woo JS, Kim DH, Allen PD, et al. TRPC3-interacting triadic proteins in skeletal muscle. Biochem J. 2008; 411(2): 399-405.

80. Skeie GO, Mygland A, Treves G, et al. Ryanodine receptor antibodies in myasthenia gravis: epitope mapping and effect on calcium release in vitro. Muscle Nerve. 2003; 27(1): 81-89.

81. Kusner LL, Mygland $\AA$, Kaminski HI. Ryanodine receptor gene expression thymomas. Muscle Nerve. 1998; 21(10): 1299-1303.

82. Bhat MB, Zhao J, Takeshima H, et al. Functional release channel formed by the carboxyl-terminal protein of ryanodine receptor. Biophys. 1997; 73(3): 1329-1336.

83. Lee EH, Cherednichenko G, Pessah IN, et al. Functional coupling between TRPC3 and RyR1 regulates the expression of key triadic proteins. J Biol Chem. 2006; 281(15): 10042-10048.

84. Woo JS, Kim DH, Allen PD, et al. TRPC3-interacting triadic proteins in skeletal muscle. Biochem J. 2008; 411(2): 399-405.

85. Takamori M. Lambert-Eaton myasthenic syndrome: search for alternative autoimmune targets and possible compensatory mechanisms based on presynaptic calcium homeostasis. J Neuroimmunol. 2008; 201-202: 145-152.

86. Takamori M, Maruta T, Komai K. Lambert-Eaton myasthenic syndrome and an autoimmune calcium-channelopathy. Neurosci Res. 2000; 36(3): 183-191.

87. Takamori M, Hamada T, Komai K, et al. Synaptotagmin can cause an immune-mediated model of Lambert-Eaton myasthenic syndrome in rats. Ann Neurol. 1994; 35(1): 74-80.

88. Takamori M, Takahashi M, Yasukawa Y, et al. Antibodies to recombinant synaptotagmin and calcium channel subtypes in Lambert-Eaton myasthenic syndrome. J Neurol Sci. 1995; 133(1-2): 95-101.

89. Takamori M. Structure of the neuromuscular junction: function and cooperative mechanisms in the synapse. Ann NY Acad Sci. 2012; 1274: 14-23.

90. Santafé MM, Lnuza MA, Garcia N, et al. Muscarinic autoreceptors modulate transmitter release through protein kinase $\mathrm{C}$ and protein kinase A in the rat nerve terminal. Eur J Neurosci. 2006; 23(8): 20482056.

91. Marx A, Pfister F, Schalke B, et al. The different roles of the thymus in the pathogenesis of the various myasthenia gravis subtypes. Autoimmun Rev. 2013; 12: 875-884.

92. Gradolatto A, Nazzal D, Foti M, et al. Defects of immunoregulatory mechanisms in myasthenia gravis: role of IL-17. Ann NY Acad Sci. 2012; 1274: 40-47. 
93. Cavalcante P, Cufi P, Mantegazza R, et al. Etiology of myasthenia gravis: innate immunity signature in pathological thymus. Autoimmun Rev. 2013; 12: 863-874.

94. Cordiglieri C, Marolda R, Franzi S, et al. Innate immunity in myasthenia gravis thymus: pathogenic effects of Toll-like receptor 4 signaling on autoimmunity. J Autoimmun. 2014; 52: 74-89.

95. Maury JM, du Vignaux CM, Drevet G, et al. Activation of the mTOR/Akt pathway in thymic epithelial cells derived from thymoma. PLoS ONE. 2019; 14(3): e0197655.

96. Robinet M, Maillard S, Cron MA, et al. Review on Toll-like receptor activation in myasthenia gravis: Application to the development of new experimental models. Clin Rev Allergy Immunol. 2017; 52(1): 133-147.

97. Hajishengallis G, Lambris JD. More than complementing tolls: Complement-Toll-like receptor synergy and crosstalk in innate immunity and inflammation. Clin Rev Allergy Immunol. 2016; 274(1): 233-344.

98. Fujii YX, Tashiro A, Arimoto K, et al. Diminished antigen-specific IgG1 and interleukin- 6 production and acetylcholinesterase expression in combined M1 and M5 muscarinic acetylcholine receptor knockout mice. J Neuroimmunol. 2007; 188(1-2): 80-85.

99. Fujii T, Mashimo M, Moriwaki Y, et al. Expression and function of the cholinergic system in immune cells. Front Immunol. 2017; 8: 10851101.

100. Beecher G, Anderson D, Siddigi ZA. Rituximab in refractory myasthenia gravis: Extended prospective study results. Muscle Nerve. 2018; 58(3): 452-455.

101. Howard JF Jr, Utsugisawa K, Benatar M, et al. REGAIN study Group. Safety and efficacy of eculizumab in anti-acetylcholine receptor antibody-positive refractory generalized myasthenia gravis (REGAIN): a phase 3, randomized, double-blind, placebo-controlled multicenter study. Lancet Neurol. 2017; 16(12): 976-986.

102. Kusner LL, Yucius K, Sengupta M, et al. Investigational RNAi therapeutic targeting $\mathrm{C} 5$ is efficacious in pre-clinical modes of myasthenia gravis. Mol Ther Methods Clin Dev. 2019; 13: 484-492.

103. Camacho LH. CTLA-4 blockade with ipilimuma: biology, safety, efficacy, and future considerations. Cancer Med. 4(5): 661-672.

104. Jonsson DI, Pirskanen R, Piehl F. Beneficial effect of tocilizumab in myasthenia gravis refractory to rituximab. Neuromuscul Disord. $2017 ; 27(6)$ : 565-568.
105. Kryczanowsky F, Raker V, Graulich E, et al. IL-10-modulated human dendritic cells for clinical use: identification of a stable and migratory subset with improved tolerlogenic activity. J Immunol. 2016; 197(9): 3607-3617.

106. Jagoumintzis G, Zisimopoulou P, Tarakas N, et al. Scale up and safety parameters of antigen specific immunoadsorption of human antiacetylcholine receptor antibodies. J Neuroimmunol. 2014; 267(1-2): $1-6$.

107. Howard JF Jr, Bril V, Burns TM, et al. Randomized phase 2 study of FcRn antagonist efgartigimod in generalized myasthenia gravis. Neurology. 2019; 92(23): e2661-e2673.

108. Liu RT, Zhang P, Yang CL, et al. ONX-0914, a selective inhibitor of immunoproteasome, ameliorates experimental autoimmune myasthenia gravis by modulating humoral response.J Neuroimmunol 2017; 311: 71-78.

109. Dong YF, Guo RB, Ji J, et al. S1PR3 is essential for phosphorylated fingolimod to protect astrocytes against oxygen-glucose deprivationinduced neuroinflammation via inhibiting TRL2/4-NFKB signaling. J Cell Mol Med. 2018; 22(6): 3159-3166.

110. Spindel ER. Cholinergic targets in lung cancer. Curr Pharm Des. 2016; 22(14): 2152-2159.

111. Roberts A, Perera S, Lang B, et al. Paraneoplastic myasthenic syndrome IgG inhibits $45 \mathrm{Ca} 2+$ flux in a human small cell carcinoma line. Nature. 1985; 317(6039): 737-739.

112. Benatar M, Blaes F, Johnston I, et al. Presynaptic neuronal antigens expressed by a small cell lung carcinoma cell line. J Neuroimmunol. 2012; 113(1): 153-162.

113. Oguro-Okano M, Griesmann GE, Wieben ED, et al. Molecular diversity of neuronal-type calcium channels identified in small cell lung carcinoma. Mayo Clin Proc. 1992; 67(12): 1150-1159.

114. David P, el Far C, Martin-Mouto N, et al. Expression of synaptotagmin and syntaxin associated with $\mathrm{N}$-type calcium channels in small cell lung cancer. FEBS Lett. 1993; 326(1-3): 135-139.

115. Vincent A, Lang B, Newsom-Davis J. Autoimmunity to the voltagegated calcium channel underlies the Lambert-Eaton myasthenic syndrome, a paraneoplastic disorder. Trends Neurosci. 1989; 12(12): 496-502.

116. Spindel ER. Muscarinic receptor agonists and antagonists: effects on cancer. Handb Exp Pharmacol. 2012; (208): 451-468. 